\title{
Implikasi multimedia interaktif berbasis flash terhadap motivasi dan prestasi belajar matematika
}

\author{
Edi Irawan ${ }^{1}$, Tatik Suryo ${ }^{2}$
}

\begin{abstract}
Abstrak: Penelitian ini bertujuan untuk menguji efektivitas penggunaan multimedia berbasis flash pada mata kuliah statistika ditinjau dari motivasi belajar dan prestasi belajar mahasiswa. Penelitian ini adalah penelitian eksperimen semu dengan desain pretest-posttest nonequivalent group design. Penelitian ini dilaksanakan di STKIP PGRI Pacitan pada tahun 2016. Instrumen yang digunakan adalah tes prestasi belajar dan angket motivasi belajar mahasiswa. Teknik analisis data yang digunakan adalah uji one sample t-test, uji $T^{2}$ Hotelling's, dan uji $t$-Bonferroni. Hasil penelitian menunjukkan bahwa penggunaan multimedia berbasis flash pada mata kuliah statistika lebih efektif daripada pembelajaran menggunakan media powerpoint ditinjau dari motivasi belajar dan prestasi belajar mahasiswa. Prestasi belajar statistika mahasiswa yang menggunakan media flash lebih baik daripada mahasiswa yang menggunakan media powerpoint. Demikian halnya pada aspek motivasi belajar, mahasiswa yang menggunakan flash mengalami peningkatan motivasi yang lebih signifikan daripada mahasiswa yang menggunakan media powerpoint.
\end{abstract}

Kata kunci: Multimedia Flash; Motivasi Belajar; Prestasi Belajar; Statistika

\begin{abstract}
This study aims to test the effectiveness of the use of flashbased multimedia in the course of statistics toward learning motivation and student achievement. This research is a quasi-experimental research with pretest-posttest nonequivalent group design. This research was conducted at STKIP PGRI Pacitan in 2016. The instrument used was the test of student achievement and questionnaire of student's motivation. Data analysis techniques used one sample t-test, T2 Hotelling's test, and t-Bonferroni test. The results showed that the use of flash-based multimedia in the course of statistics is more effective than learning using powerpoint in terms of learning motivation and student achievement. Students' achievement in statistics using flash media are better than students who use powerpoint. Similarly, in the aspect of motivation to learn, the
\end{abstract}

\footnotetext{
1 IAIN Ponorogo, Ponorogo, Indonesia, ediirawan@stainponorogo.ac.id

2 STKIP PGRI Pacitan, Pacitan, Indonesia
} 
motivation of students who use flash get increased significantly than students who use powerpoint.

Keywords: Flash Multimedia; Learning Motivation; Achievement; Statistics

\section{A. Pendahuluan}

Statistika merupakan salah satu mata kuliah yang sangat penting sehingga harus dikuasai dengan baik dan benar oleh mahasiswa. Namun demikian, statistika dianggap oleh sebagian besar mahasiswa sebagai salah satu mata kuliah yang rumit, sulit, dan memusingkan (Ulpah, 2009). Terlebih, untuk kalangan non eksakta, memandang statistika sebagai ilmu yang sangat dibenci karena terlalu banyak rumus yang harus di hafal (Ramsey, 1999). Akibatnya, ketakutan terhadap statistika membuat penguasaan konsep terhadap statistika juga rendah.

Fenomena rendahnya penguasaan konsep statistika juga dialami mahasiswa STKIP PGRI Pacitan. Berdasarkan hasil penelitian terdahulu pada tahun 2012 menyebutkan bahwa penguasaan konsep statistika mahasiswa STKIP PGRI Pacitan, khususnya pada uji komparasi sederhana menggunakan uji-t dan uji-z masih rendah (Irawan, 2012). Hal ini sejalan dengan hasil observasi awal yang dilakukan pada pertemuan awal, bahwa penguasaan konsep dasar statistika mahasiswa masih sangat rendah. Rendahnya penguasaan konsep statistika mencerminkan rendahnya prestasi belajar statistika. Salah satu aspek lain yang menjadi penyebab rendahnya prestasi belajar statistika adalah motivasi belajar mahasiswa terhadap statistika juga masih rendah. Hal ini teridentifikasi dengan realita yang terlihat ketika proses perkuliahan sebagian mahasiswa terlihat kurang memperhatikan, berbicara dengan teman, mengantuk, dan kurang aktif dalam memecahkan soal yang bersifat tantangan.

Setiap proses belajar pasti akan membuahkan perubahan konstruksi pemikiran dari diri pembelajar. Hasil capaian belajar inilah yang disebut dengan prestasi belajar. Prestasi belajar diartikan sebagai pengetahuan, keterampilan, dan kemampuan yang mahasiswa kembangkan sebagai suatu hasil pelajaran (Nitko \& Brookhart, 2011). Prestasi belajar dipengaruhi oleh dua faktor yaitu faktor internal (bersumber dari dalam 
diri mahasiswa) dan faktor eksternal (bersumber dari luar mahasiswa). Faktor internal meliputi faktor jasmaniah, faktor psikologis dan faktor kelelahan, sedangkan faktor ekstern meliputi faktor keluarga, faktor sekolah dan faktor masyarakat (Slameto, 1995). Secara teknis, untuk mengukur dan mengevaluasi tingkat keberhasilan belajar, dapat dilakukan melalui tes prestasi belajar (Djamarah \& Zain, 2006).

Selain memperhatikan aspek kognitif, dalam proses pembelajaran Dosen hendaknya memperhatikan permasalahan dari segi psikis atau afektif. Sebab, tidak sedikit pula mahasiswa yang memiliki masalah dari segi psikis atau afektif. Salah satu aspek dari segi psikis atau afektif adalah motivasi belajar mahasiswa. Motivasi belajar merupakan aspek afektif yang menunjang keberhasilan proses pembelajaran termasuk pembelajaran statistika. Motivasi belajar merupakan faktor psikis yang bersifat non-intelektual (Sardiman, 2012). Motivasi yang kuat dalam diri peserta didik akan meningkatkan minat, kemauan dan semangat yang tinggi dalam belajar, karena antara motivasi dan semangat belajar mempunyai hubungan yang erat. Secara umum, orang yang mempunyai motivasi yang lebih besar akan meraih hasil yang lebih tinggi (Elliott \& Littlefield, 2000). Betapa pentingnya peranan motivasi juga diungkapkan oleh Orlich, bahwa "...teacher can teach only if the learner has some desire to learn. We call the desire in motivation" (C Orlich, 2010). Hal ini menunjukkan betapa penting dan berartinya keberadaan motivasi dalam pembelajaran.

Motivasi belajar adalah dorongan yang menggerakan, mengarahkan, dan mempertahankan perilaku mahasiswa dalam kegiatan belajar statistika, yang timbul dari dalam ataupun dari luar diri siswa, yang tercermin dari kebutuhan, usaha dan ketekunan untuk mencapai hasil belajar sebaik mungkin. Seseorang yang belajar dengan motivasi tinggi akan melaksanakan kegiatan belajarnya dengan sungguh-sungguh, penuh semangat dan gairah. Sebaliknya mahasiswa yang belajar dengan motivasi rendah akan menjadi malas bahkan tidak mau mengerjakan tugas-tugas yang berhubungan dengan pelajaran (Dai \& Sternberg, 2004).

Adapun faktor-faktor yang mempengaruhi motivasi belajar pada tahap awal pembelajaran menurut Elliott adalah "there are two key motivational factors involved at this stage: attitudes and needs" (Elliott \& Littlefield, 2000). Reid menyatakan bahwa suatu saat tidak semua peserta 
didik termotivasi secara intuitif dan intrinsik untuk belajar (Reid, 2007). Beberapa mahasiswa butuh untuk dimotivasi sehingga Dosen harus mengembangkan peralatan dan metode agar memungkinkan dan memfasilitasi motivasi belajar ini. Ada beberapa bentuk dan cara untuk menumbuhkan motivasi antara lain: memberi nilai, hadiah, saingan atau kompetisi, ego-involvement, memberi ulangan, pujian, hukuman, hasrat untuk belajar, minat, dan tujuan yang diakui (Sardiman, 2012).

Perkembangan di bidang teknologi informasi dan komunikasi yang sangat masif, memberikan andil terhadap dunia pendidikan khususnya pada kegiatan pembelajaran. Saat ini telah banyak perangkat lunak yang dapat digunakan sebagai pendukung dalam proses pembelajaran. Sebut saja ada Powerpoint, Macromedia Flash, Videoscribd, Video Tutorial, dan lainnya yang biasa digunakan untuk menyampaikan materi. Powerpoint adalah software pembuat media pembelajaran yang sangat familiar dan banyak digunakan sedangkan macromedia flash merupakan perangkat lunak yang lebih menarik dan interaktif, namun masih terbatas penggunannya di dunia pendidikan. Macromedia Flash, merupakan software yang dirancang untuk membuat animasi berbasis vektor dengan hasil yang mempunyai ukuran yang kecil. Sejak diluncurkan pertama kali, Macromedia Flash telah banyak mengalami perkembangan dan peningkatan. Macromedia Flash dapat digunakan untuk mengembangkan game atau bahan ajar seperti kuis atau simulasi.

Macromedia flash dipilih untuk mengembangkan multimedia pembelajaran pada mata kuliah statistika karena menghasilkan produk yang sangat menarik dan bervariasi. Di samping itu, macromedia flash juga mudah untuk digunakan untuk seorang peneliti pemula. Bahkan, software ini juga dilengkapi dengan beberapa template dan komponen pendukung lainnya (Sutarti, Sugiyono, Irawan, \& Prasetyo, 2015).

Macromedia flash merupakan software yang sangat cocok digunakan untuk membuat media pembelajaran interaktif, termasuk halnya pada materi statistika (Sutarti, Sugiyono, \& Irawan, 2015). Pernyataan ini sejalan dengan beberapa hasil penelitian lain yang menunjukkan bahwa penggunaan multimedia berbasis flash dapat meningkatkan prestasi belajar peserta didik (Mawarni, Mulyani, \& Yamtinah, 2014; Retnani, Sukardjo, \& Utomo, 2014; Asiyah, Mulyani, \& Nurhayati, 2013; dan Arfiyani, Haryono, \& Mulyani, 2014). 
Sejalan dengan uraian di atas, maka yang menjadi penting dan menarik untuk mendeskripsikan efektivitas penggunaan multimedia berbasis flash pada mata kuliah statistika ditinjau dari motivasi belajar dan prestasi belajar mahasiswa. Diharapkan penelitian ini akan mampu memberikan sumbangan terhadap perkembangan khasanah keilmuan, terutama yang berkaitan dengan pengembangan media pembelajaran berbasis flash. Secara spesifik, penelitian ini ditujukan untuk mengetahui bagaimana efektivitas penggunaan multimedia flash pada mata kuliah statistika ditinjau dari aspek prestasi dan motivasi belajar mahasiswa.

\section{B. Metode Penelitian}

Jenis penelitian ini adalah eksperimen semu (quasi-experiment) dengan desain pretest-posttest nonequivalent group design. Penelitian ini dilakukan di STKIP PGRI Pacitan dari bulan Mei sampai dengan Juni tahun 2016. Populasi pada penelitian ini adalah seluruh mahasiswa Semester $V$ STKIP PGRI Pacitan. Dua kelas dipilih secara acak, di mana satu kelas ditetapkan sebagai kelas eksperimen yang diberi perlakuan dengan menggunakan multimedia berbasis flash dan satu kelas yang lain menggunakan media Powerpoint. Berikut adalah salah satu contoh tampilan kedua media tersebut.

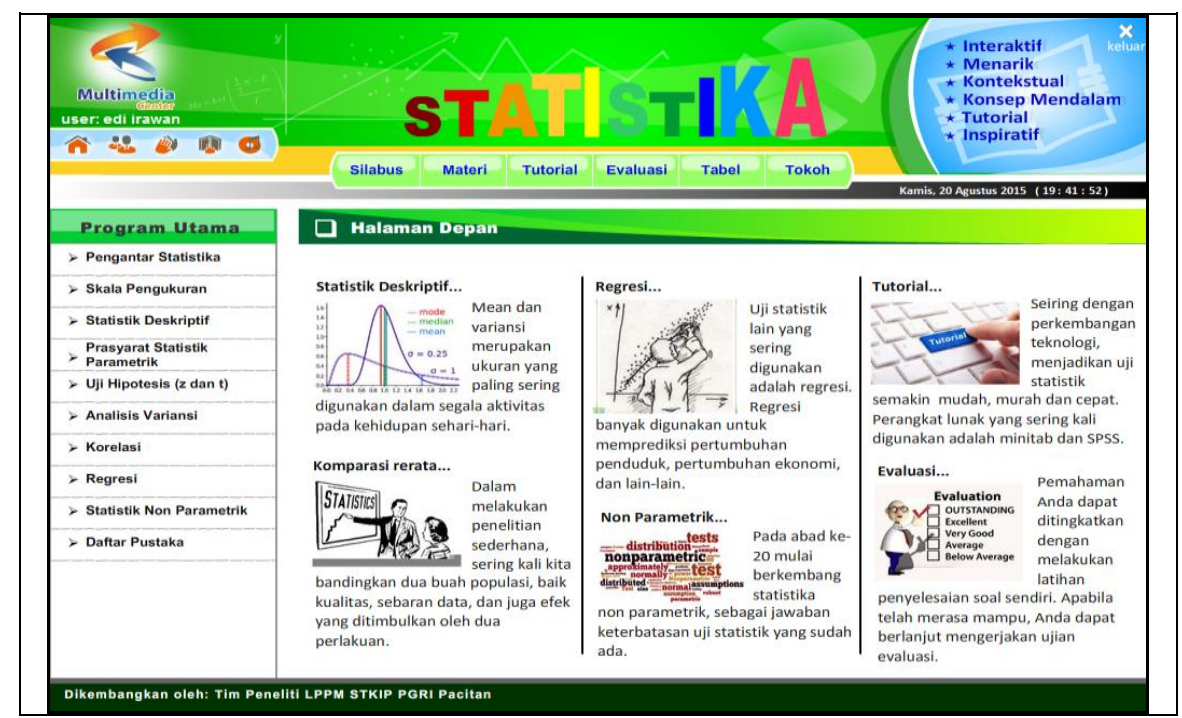

Gambar 1. Tampilan Menu Utama Media Flash 


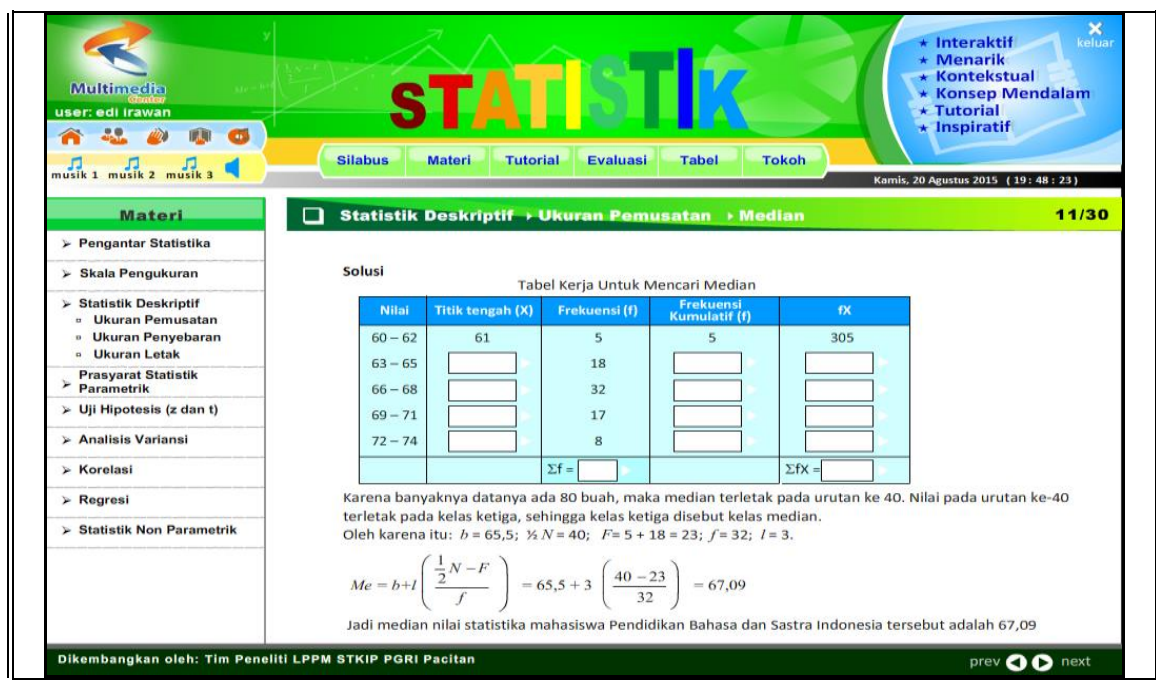

Gambar 2. Contoh Tampilan Halaman Interaktif Media Flash

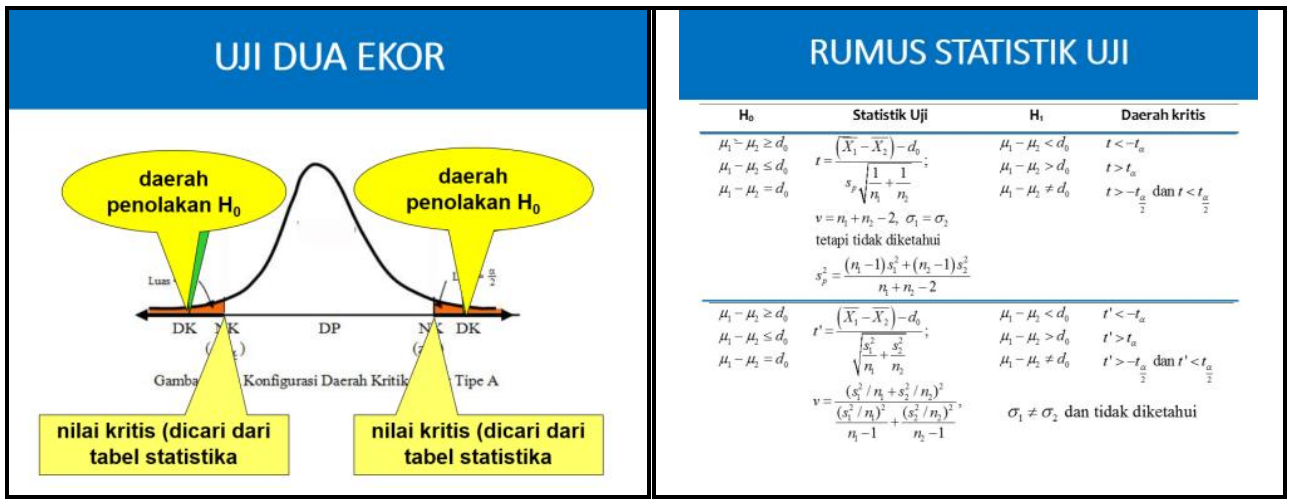

Gambar 3. Contoh Tampilan Materi Powerpoint

Gambar 4. Contoh Tampilan Rumus Pada Materi Powerpoint

Media pembelajaran flash di atas telah dikembangkan secara prosedural dan juga telah mendapatkan validasi dari judgment expert. Hasil penilaian yang dilakukan oleh expert judgment tersebut menunjukkan bahwa media pembelajaran yang dikembangkan sudah valid dan sangat baik, baik dari aspek rekayasa perangkat lunak, desain pembelajaran, maupun komunikasi visual (Sutarti dkk, 2015).

Terdapat tiga variabel yang terlibat pada penelitian ini, satu variabel bebas dan dua variabel terikat. Variabel bebas pada penelitian ini adalah media pembelajaran dan variabel terikatnya adalah motivasi belajar dan 
prestasi belajar statistika. Instrumen yang digunakan untuk mengukur prestasi belajar adalah tes prestasi belajar statistika yang terdiri atas dua soal uraian dan instrumen yang digunakan untuk mengukur motivasi belajar adalah angket motivasi belajar yang terdiri atas tiga puluh item yang berbentuk checklist.

Teknik pengumpulan data diawali dengan memberikan tes dan angket sebelum perlakuan terhadap sampel yang telah ditentukan. Setelah itu, dilanjutkan dengan pemberian perlakuan pengajaran dengan menggunakan multimedia berbasis flash pada kedua kelas eksperimen. Selanjutnya, diakhiri dengan pemberian tes dan angket setelah perlakuan terhadap kedua sampel tersebut.

Teknik analisis data yang dilakukan pada penelitian ini adalah analisis deskriptif dan analisis inferensial. Analisis deskriptif dilakukan dengan mencari rata-rata, standar deviasi, varians, skor minimal, dan skor maksimal dari data yang diperoleh kedua kelompok, baik untuk sebelum perlakuan, maupun untuk setelah perlakuan. Sedangkan analisis inferensial dilakukan dengan uji asumsi, uji keefektifan, dan uji perbedaan keefektifan.

Sebelum perlakuan, dilakukan uji MANOVA untuk melihat apakah terdapat perbedaan kemampuan awal antara dua kelas sampel pada pembelajaran statistika ditinjau dari aspek prestasi belajar dan motivasi belajar mahasiswa. Pengujian dilakukan dengan menggunakan Uji Hotelling's Trace sebagai berikut:

$$
T^{2}=\frac{n_{1} n_{2}}{n_{1}+n_{2}} D^{2}
$$

Di mana $T^{2}$ adalah Hotelling's Trace, $n_{1}$ adalah banyak sampel pada kelompok I, dan $n_{2}$ adalah banyak sampel pada kelompok II. $D^{2}=\left(\bar{y}_{1}-\bar{y}_{2}\right)^{\prime} s^{-1}\left(\bar{y}_{1}-\bar{y}_{2}\right)$ di mana $\bar{y}_{1}-\bar{y}_{2}$ adalah selisih mean vektor sampel dan $\mathrm{s}^{-1}$ adalah invers matriks kovariansi (Bernstein, 2012).

Setelah memperoleh nilai $T^{2}$ Hotteling's, nilai tersebut selanjutnya ditransformasikan untuk memperoleh nilai distribusi $F$ dengan formula sebagai berikut:

$$
F=\left(\frac{n_{1}+n_{2}-p-1}{p}\right)\left(\frac{T^{2}}{n_{1}+n_{2}-2}\right)
$$


Dengan $p$ adalah banyaknya variabel terikat. Kriteria pengujiannya adalah $H_{0}$ ditolak jika $F_{h i t} \geq F_{\alpha\left(p ; n_{1}+n_{2}-p-1\right)}$ (Bernstein, 2012).

Setelah diketahui bahwa tidak terdapat perbedaan kemampuan awal antara kedua kelompok, dilakukan eksperimen. Kelompok eksperimen 1 dilakukan pembelajaran dengan menggunakan multimedia interaktif berbasis flash, sedangkan kelompok eksperimen 2 dilakukan pembelajaran dengan menggunakan media Powerpoint. Selanjutnya, dilakukan uji untuk melihat apakah terdapat perbedaan efektivitas penggunaan multimedia interaktif ditinjau dari aspek prestasi belajar dan motivasi belajar mahasiswa dengan menggunakan uji MANOVA sebagaimana tercantum pada persamaan (1) dan (2) di atas. Jika terdapat perbedaan keefektifan, maka selanjutnya dilakukan uji $t$ Bonferoni untuk melihat apakah penggunaan multimedia interaktif berbasis flash lebih efektif daripada pembelajaran menggunakan media powerpoint ditinjau dari kedua aspek tersebut dengan menggunakan uji $t$ sebagai berikut.

$$
t=\frac{\bar{y}_{i 1}-\bar{y}_{i 2}}{\sqrt{\frac{\left(n_{1}-1\right) s_{1}^{2}+\left(n_{2}-1\right) s_{2}^{2}}{n_{1}+n_{2}-2}\left(\frac{1}{n_{1}}+\frac{1}{n_{2}}\right)}}
$$

Dengan $\bar{y}_{i 1}$ adalah nilai rata-rata variabel ke $i$ sampel $\mathrm{I}, \bar{y}_{i 2}$ adalah nilai rata-rata variabel ke i sampel $\mathrm{II}, s_{1}^{2}$ adalah variansi sampel I, $s_{2}^{2}$ adalah variansi sampel II, $n_{1}$ adalah banyak anggota sampel I, $n_{2}$ adalah banyak anggota sampel II dan $i$ adalah variabel bebas. Kriteria pengujiannya adalah $H_{0}$ ditolak jika $t_{o b s} \geq t_{\left(\frac{\alpha}{2}, n_{1}+n_{2}-2\right)}$ (Sanders, 2001).

Sebelum dilakukan uji hipotesis, terlebih dahulu dilakukan uji asumsi yaitu uji normalitas dan uji homogenitas. Uji normalitas yang dilakukan pada penelitian ini terdiri dari dua uji, yakni uji normalitas multivariat dan uji normalitas univariat. Uji normalitas multivariat dilakukan menggunakan uji jarak Mahalanobis $\left(d_{i}^{2}\right)$ dengan kriteria keputusan bahwa data dikatakan berdistribusi normal jika sekitar 50\% data mempunyai nilai $d_{i}^{2}<\chi_{(p ; 0,5)}^{2}$ (Johnson \& Wichern, 2007). Sementara uji normalitas univariat dilakukan dengan menggunakan uji Kolmogorov- 
Smirnov, dengan kriteria keputusan bahwa data dikatakan berdistribusi normal jika $P$-Value $>\alpha$ (Irawan, 2014). Uji homogenitas matriks varian kovarian dilakukan dengan menggunakan uji Box's $M$ dengan kriteria keputusan bahwa data dikatakan homogen jika nilai signifikansi $F$ lebih besar dari 0,05 (Rencher, 1998).

\section{Temuan dan Pembahasan}

Selama satu semester, kedua media pembelajaran (media pembelajaran berbasis flash dan media pembelajaran Powerpoint) digunakan pada kelas yang berbeda. Masing-masing kelas tersebut sebelumnya telah dipilih secara random dari seluruh kelas yang ada. Pada akhir semester dilakukan post test untuk mengukur prestasi dan motivasi belajar statistika mahasiswa.

Deskripsi data prestasi belajar statistika mahasiswa yang belajar dengan menggunakan multimedia interaktif berbasis flash dan menggunakan media Powerpoint sebagaimana tersaji pada Tabel 1 di bawah ini. Sedangkan hasil angket motivasi belajar mahasiswa, tersaji pada pada Tabel 2.

Tabel 1. Deskripsi Prestasi Belajar Statistika

\begin{tabular}{|l|c|c|c|c|}
\hline \multirow{2}{*}{ Deskripsi } & \multicolumn{2}{|c|}{$\begin{array}{c}\text { Pembelajaran Menggunakan } \\
\text { Multimedia Flash }\end{array}$} & \multicolumn{2}{c|}{$\begin{array}{c}\text { Pembelajaran Menggunakan } \\
\text { Media Powerpoint }\end{array}$} \\
\cline { 2 - 5 } & Pretest & Post-test & Pretest & Post-test \\
\hline Rata-rata & 63,37 & 82,64 & 63,48 & 79,67 \\
\hline Standar Deviasi & 7,12 & 7,67 & 7,78 & 9,70 \\
\hline Variansi & 50,72 & 58,75 & 60,65 & 94,07 \\
\hline Skor Maksimum & 76 & 99 & 78 & 97 \\
\hline Skor Minimum & 50 & 65 & 51 & 63 \\
\hline
\end{tabular}

Tabel 2. Deskripsi Motivasi Belajar Mahasiswa

\begin{tabular}{|l|c|c|c|c|}
\hline \multirow{2}{*}{ Deskripsi } & \multicolumn{2}{|c|}{$\begin{array}{c}\text { Pembelajaran Menggunakan } \\
\text { Multimedia Flash }\end{array}$} & $\begin{array}{c}\text { Pembelajaran Menggunakan } \\
\text { Media Powerpoint }\end{array}$ \\
\cline { 2 - 5 } & Pretest & Posttest & Pretest & Posttest \\
\hline Rata-rata & 83,27 & 92,62 & 84,68 & 86,61 \\
\hline Standar Deviasi & 6,32 & 5,63 & 7,18 & 6,37 \\
\hline Variansi & 39,94 & 31,69 & 51,55 & 40,58 \\
\hline Skor Maksimum & 89 & 97 & 87 & 89 \\
\hline Skor Minimum & 73 & 85 & 74 & 80 \\
\hline
\end{tabular}


Berdasarkan paparan data sebagaimana tercantum pada Tabel 1 dan Tabel 2 di atas, diketahui bahwa terjadi peningkatan prestasi belajar mahasiswa. Namun demikian, peningkatan prestasi belajar statistika mahasiswa yang belajar dengan menggunakan multimedia interaktif berbasis flash jauh lebih besar daripada pembelajaran dengan menggunakan media Powerpoint.

Sebelum uji hipotesis dilakukan, terlebih dahulu dilakukan uji asumsi yaitu uji normalitas dan uji homogenitas. Uji normalitas yang dilakukan dibagi menjadi dua, yaitu uji normalitas multivariat (menggunakan jarak Mahalanobis) dan uji normalitas univariat (menggunakan uji KolmogorovSmirnov). Adapun hasil uji normalitas multivariat dan univariat untuk sebelum dan setelah perlakuan, baik untuk kelas yang menggunakan multimedia interaktif berbasis flash, maupun untuk kelas yang tidak menggunakan multimedia interaktif berbasis flash, secara berturut-turut bisa dilihat pada Tabel 3 dan Tabel 4 berikut.

Tabel 3. Hasil Uji Normalitas Multivariat

\begin{tabular}{|l|c|c|}
\hline Jenis Media Pembelajaran & $\left(d_{i}^{2}\right)$ Sebelum Perlakuan & $\left(d_{i}^{2}\right)$ Sesudah Perlakuan \\
\hline Macromedia Flash & $51,12 \%$ & $53,72 \%$ \\
\hline Powerpoint & $54,25 \%$ & $50,98 \%$ \\
\hline
\end{tabular}

Tabel 3 di atas menunjukkan bahwa sekitar 50\% data mempunyai nilai $d_{i}^{2}<\chi_{(2 ; 0,5)}^{2}$. Hal ini mengindikasikan bahwa data sebelum dan setelah perlakuan berasal dari populasi yang berdistribusi normal multivariat.

Tabel 4. Hasil Uji Normalitas Univariat

\begin{tabular}{|l|c|c|c|c|}
\hline \multirow{2}{*}{$\begin{array}{c}\text { Jenis Media } \\
\text { Pembelajaran }\end{array}$} & \multicolumn{2}{|c|}{$\begin{array}{c}\text { Signifikansi Sebelum } \\
\text { Perlakuan }\end{array}$} & \multicolumn{2}{c|}{$\begin{array}{c}\text { Signifikansi Sesudah } \\
\text { Perlakuan }\end{array}$} \\
\cline { 2 - 5 } & Prestasi & Motivasi & Prestasi & Motivasi \\
\hline Macromedia Flash & 0,714 & 0,432 & 0,235 & 0,751 \\
\hline Powerpoint & 0,547 & 0,615 & 0,327 & 0,418 \\
\hline
\end{tabular}

Tabel 4 di atas menunjukkan bahwa nilai signifikansi seluruh kelompok perlakuan, baik pada prestasi belajar maupun motivasi belajar lebih besar dari 0,05 . Sesuai aturan yang ada dapat disimpulkan bahwa asumsi normalitas univariat pada seluruh aspek telah terpenuhi.

Setelah salah satu prasyarat normalitas terpenuhi, selanjutnya dilakukan uji homogenitas, yakni homogenitas variansi dan homogenitas 
varian-kovarians. Uji homogenitas matriks varians-kovarians dilakukan dengan menggunakan uji Box's M sedangkan uji homogenitas variansi dilakukan dengan menggunakan uji Levene Statistic. Ringkasan uji homogenitas varian-kovarian, baik sebelum maupun sesudah perlakuan tertera pada Tabel 5 di bawah ini.

Tabel 5. Hasil Uji Homogenitas Matriks Varians-Kovarians

\begin{tabular}{|c|c|c|}
\hline Komponen & Sebelum Perlakuan & Sesudah Perlakuan \\
\hline Box's $M$ & 2,853 & 3,215 \\
\hline$F$ & 0,917 & 0,876 \\
\hline Sign. & 0,432 & 0,567 \\
\hline
\end{tabular}

Berdasarkan Tabel 5, diperoleh informasi bahwa nilai signifikansi $F$ lebih besar dari 0,05. Atau dengan kata lain, data prestasi belajar dan motivasi belajar mahasiswa untuk sebelum dan setelah perlakuan sudah memenuhi asumsi homogenitas matriks varians-kovarians. Selanjutnya, ringkasan uji homogenitas univariat dapat dilihat pada Tabel 6 berikut ini:

Tabel 6. Hasil Uji Homogenitas Matriks Variansi

\begin{tabular}{|c|c|c|c|c|}
\hline \multirow{2}{*}{ Komponen } & \multicolumn{2}{|c|}{ Prestasi Belajar } & \multicolumn{2}{c|}{ Motivasi Belajar } \\
\cline { 2 - 5 } & $\begin{array}{c}\text { Sebelum } \\
\text { Perlakuan }\end{array}$ & $\begin{array}{c}\text { Sesudah } \\
\text { Perlakuan }\end{array}$ & $\begin{array}{c}\text { Sebelum } \\
\text { Perlakuan }\end{array}$ & $\begin{array}{c}\text { Sesudah } \\
\text { Perlakuan }\end{array}$ \\
\hline F & 0,354 & 0,113 & 0,275 & 0,048 \\
\hline Sig. & 0,675 & 0,738 & 0,752 & 0,827 \\
\hline
\end{tabular}

Berdasarkan Tabel 6, diperoleh informasi bahwa nilai signifikansi menggunakan uji Levene lebih besar dari 0,05. Hal ini mengindikasikan bahwa asumsi homogenitas matriks variansi terpenuhi.

Selanjutnya, hasil uji mengenai keefektifan penggunaan multimedia interaktif berbasis flash pada pembelajaran statistika ditinjau dari aspek prestasi belajar dan motivasi belajar mahasiswa tersaji pada Tabel 7.

Tabel 7. Hasil MANOVA Sebelum dan Setelah Perlakuan

\begin{tabular}{|l|c|c|}
\hline \multicolumn{1}{|c|}{ Waktu Tes } & $\boldsymbol{F}_{\text {hit }}$ & Sig. \\
\hline Sebelum Perlakuan & 1,375 & 0,429 \\
\hline Setelah Perlakuan & 2,189 & 0,000 \\
\hline
\end{tabular}

Dari Tabel 7, diperoleh informasi bahwa nilai signifikansi $\mathrm{F}$ lebih besar dari 0,05 untuk data sebelum perlakuan dan kurang dari 0,05 untuk data setelah perlakuan. Artinya, sebelum perlakuan, kedua kelompok memiliki kemampuan awal yang setara. Sementara setelah perlakuan, terdapat perbedaan keefektifan penggunaan multimedia interaktif berbasis flash 
pada pembelajaran statistika ditinjau dari aspek prestasi belajar statistika dan motivasi belajar mahasiswa.

Setelah diketahui bahwa terdapat perbedaan keefektifan antara kedua media, maka dilakukan uji $t$-Bonferoni untuk melihat apakah pada mata kuliah statistika, multimedia interaktif berbasis flash lebih efektif daripada media Powerpoint, ditinjau dari aspek prestasi belajar dan motivasi belajar mahasiswa. Hasil uji $t$-Bonferoni bisa dilihat pada Tabel 8 di bawah ini.

Tabel 8. Hasil Uji t-Bonferoni

\begin{tabular}{|l|c|c|c|}
\hline \multicolumn{1}{|c|}{ Aspek } & t-Bonferoni & $\boldsymbol{t}_{(0,05: 60)}$ & Keputusan \\
\hline Prestasi Belajar & 2,0219 & 1,671 & $\mathrm{H}_{0}$ Ditolak \\
\hline Motivasi Belajar & 2,8456 & 1,671 & $\mathrm{H}_{0}$ Ditolak \\
\hline
\end{tabular}

Berdasarkan Tabel 8, diperoleh informasi t-Bonferoni $>t_{(0,05: 60)}$. Sehingga, dapat disimpulkan bahwa pembelajaran statistika dengan menggunakan multimedia interaktif berbasis flash lebih efektif daripada pembelajaran menggunakan media Powerpoint, baik ditinjau dari aspek prestasi belajar maupun dari aspek motivasi belajar mahasiswa.

Prestasi belajar statistika mahasiswa yang belajar menggunakan multimedia interaktif berbasis flash lebih baik daripada mahasiswa yang belajar menggunakan media Powerpoint. Penyebabnya, multimedia interaktif memiliki berbagai keunggulan yang tidak dimiliki oleh media lainnya. Multimedia interaktif dapat mengakomodasi cara belajar yang berbeda-beda, sebagaimana yang dikemukakan oleh Philips (1997) bahwa "IMM has the potential to accommodate people with different learning style". Multimedia interaktif juga memiliki potensi untuk menciptakan suatu lingkungan multisensori yang mendukung cara belajar tertentu.

Selain itu, keberadaan multimedia interaktif berbasis flash mendukung terjadinya pembelajaran yang lebih berpusat pada mahasiswa. Penyebabnya, multimedia interaktif lengkap dengan berbagai fasilitas seperti video tutorial, contoh soal, simulasi penyelesaian soal, dan juga latihan uji kompetensi, sebagaimana tercantum pada gambar 5, 6, 7 dan 8 di bawah. Mahasiswa memiliki keleluasaan waktu untuk belajar secara mandiri dengan mengikuti petunjuk dan tutorial yang ada dalam multimedia flash. Mahasiswa juga diberikan kesempatan untuk berlatih 
menyelesaikan soal-soal latihan kontekstual yang terkait dengan penelitian dalam bidang pendidikan.

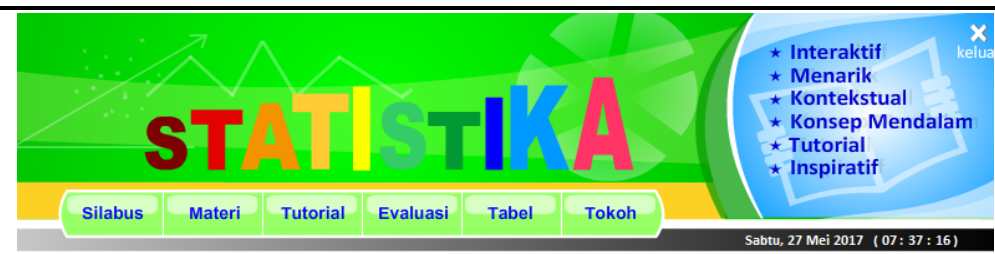

Uji Hipotesis > Uji Hipotesis Mengenai Rerata

$20 / 24$

Contoh Soal 6

Seorang dosen ingin menguji apakah prestasi matematika mahasiswa pria sama dengan prestasi mahasiswa wanita. Untuk keperluan tersebut diambil 12 wanita dan 16 pria sebagai sampel. Nilai dari sampel tersebut adalah:

$$
\begin{array}{l:l}
\text { Wanita : } & 117176816798586987747981 \\
\hline \text { Pria : } 68727779688054638974668677737487
\end{array}
$$

Jika diasumsikan bahwa sampel tersebut diambil dari populasi normal, dengan variansi-variansi populasinya tidak sama dan juga tidak diketahui, maka dengan taraf signifikansi $5 \%$ bagaimana kesimpulan penelitian tersebut? Solusi

Misalnya $\mu 1$ adalah rerata nilai mahasiswa wanita dan $\mu 2$ adalah rerata nilai mahasiswa pria.

1. $\mathrm{H}_{0}: \mu_{1}=\mu_{2}$ (mahasiswa pria dan wanita sama kemampuannya)

$\mathrm{H}_{1}: \mu_{1} \neq \mu_{2}$ (mahasiswa pria dan wanita tidak sama kemampuannya)

2. $\alpha=0,05$

3. Statistik uji yang digunakan adalah:

Gambar 5. Contoh Soal Kontekstual pada Penelitian Pendidikan

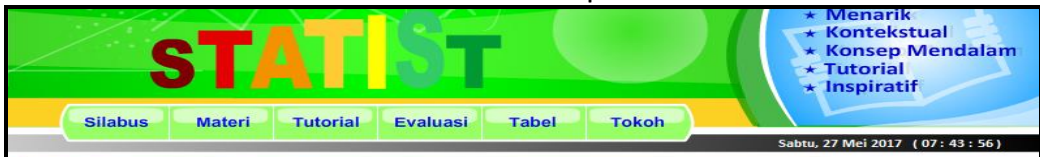

$\square$ Tutorial > Uji Normalitas \& Homogenitas

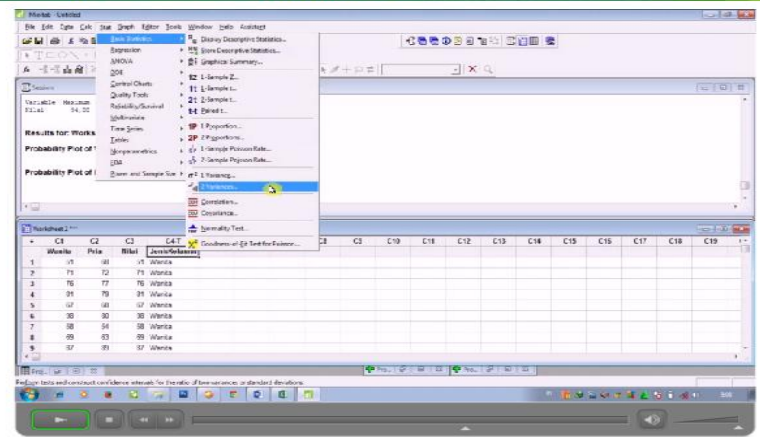

Gambar 6. Contoh Tampilan Video Tutorial Mengolah Data Menggunakan Minitab 


\section{Statistik Deskriptif - Ukuran Pemusatan > Mean}

Solusi

Tabel Kerja Untuk Mencari Rerata Nilai Statistika

\begin{tabular}{|c|c|c|c|c|c|c|}
\hline Nilai & Titik tengah ( & \multicolumn{2}{|c|}{ Frekuensi(f) } & \multicolumn{3}{|c|}{$f X$} \\
\hline $60-62$ & 61 & \multicolumn{2}{|c|}{5} & \multicolumn{3}{|c|}{305} \\
\hline $63-65$ & 64 & \multicolumn{2}{|c|}{18} & & 34 & 十 \\
\hline $66-68$ & & \multicolumn{2}{|c|}{32} & & & 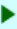 \\
\hline $69-71$ & & \multicolumn{2}{|c|}{17} & & & $\triangleright$ \\
\hline $72-74$ & & \multicolumn{2}{|c|}{8} & & & 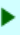 \\
\hline & & $\Sigma f=$ & $\nabla$ & $\Sigma \mathrm{fx}=$ & & $\nabla$ \\
\hline
\end{tabular}

Gambar 7. Contoh Soal Interaktif yang Dilengkapi Umpan Balik

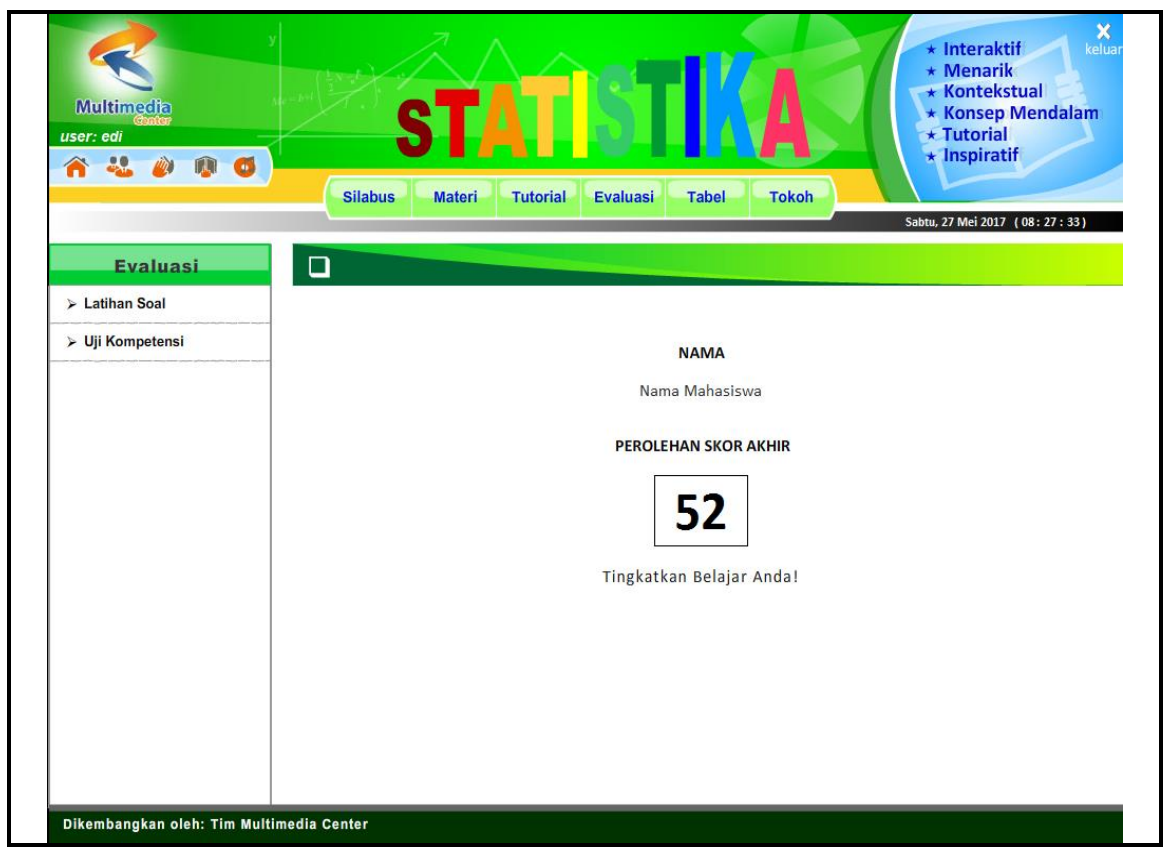

Gambar 8. Umpan Balik Setelah Mengikuti Ujian Kompetensi

Keberadaan berbagai fasilitas pada multimedia interaktif inilah yang menstimulasi peningkatan prestasi belajar mahasiswa. Hal ini sejalan dengan dengan teori kerucut pengalaman (cone of experience) yang memberikan gambaran bahwa pengalaman belajar yang diperoleh 
mahasiswa dapat melalui proses perbuatan atau mengalami sendiri apa yang dipelajari, proses mengamati dan mendengarkan melalui media tertentu dan proses mendengarkan melalui bahasa (Dale, 1946). Semakin konkret mahasiswa mempelajari bahan pelajaran, maka semakin banyak pengalaman yang diperolehnya. Pada pembelajaran menggunakan multimedia interaktif, mahasiswa bisa melihat proses, mendengarkan dan melihat video tutorial, mengamati proses penyelesaian suatu soal, bahkan berpengalaman langsung dalam menyelesaikan suatu soal.

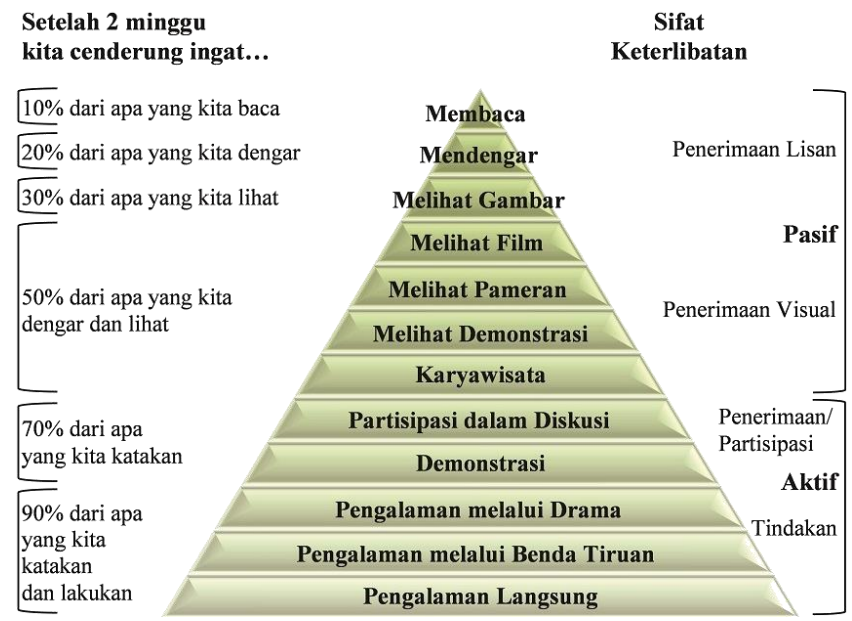

Gambar 9. Cone of Experience (Dale, 1946)

Ditilik dari aspek motivasi belajar, penggunaan multimedia interaktif berbasis flash juga mampu menumbuhkan motivasi belajar mahasiswa. Pembelajaran dengan menggunakan multimedia interaktif berbasis flash ini mengaitkan materi perkuliahan dengan kegunaannya dalam dunia nyata sehingga mereka tahu apa manfaat dari apa yang sedang mereka pelajari. Selain itu, mahasiswa juga terlibat langsung, mulai dari awal pembelajaran sampai dengan akhir pembelajaran. Pada awal pelajaran mahasiswa leluasa untuk memilih materi yang hendak dipelajari sesuai keinginan dan kebutuhan masing-masing. Selanjutnya mahasiswa bisa mempelajari materi, berlatih menyelesaikan soal, dan juga melihat tutorial. Di akhir pelajaran, mahasiswa juga bisa melakukan ujian secara mandiri, yang dilengkapi dengan umpan balik berupa nilai akhir. 
Multimedia interaktif berbasis flash memberikan dampak yang lebih baik terhadap prestasi dan motivasi belajar mahasiswa. Keunggulan yang paling menonjol pada multimedia adalah sifat interaktivitasnya. Hal ini sejalan dengan argumen Bates dan Bacon (1995) bahwa diantara mediamedia lain interaktivitas multimedia atau media lain yang berbasis komputer adalah yang paling nyata. Interaktivitas nyata di sini adalah interaktivitas yang melibatkan fisik dan mental dari pengguna saat menggunakan program multimedia. Akibatnya motivasi belajar dan prestasi belajar mahasiswa menjadi meningkat.

Hasil penelitian di atas sejalan dengan penelitian Walton dan Mayer \& McCarthy yang menyimpulkan bahwa pemanfaatan multimedia dalam pembelajaran dapat meningkatkan hasil belajar $56 \%$ lebih besar, konsistensi dalam belajar 50-60\% lebih baik dan ketahanan dalam memori 25-50\% lebih tinggi (Sidhu, 2010).

\section{Simpulan}

Berdasarkan hasil analisis data dan pembahasan, maka disimpulkan bahwa pembelajaran menggunakan multimedia interaktif berbasis flash lebih efektif dibandingkan dengan pembelajaran menggunakan media Powerpoint, apabila ditinjau dari motivasi belajar dan prestasi belajar statistika. Dengan kata lain, penggunaan multimedia interaktif berbasis flash lebih efektif dalam meningkatkan prestasi belajar statistika apabila dibandingkan dengan media Powerpoint. Selain itu, penggunaan multimedia interaktif berbasis flash juga sangat efektif dalam meningkatkan motivasi belajar statistika mahasiswa. Multimedia berbasis flash lebih efektif dalam meningkatkan prestasi dan motivasi belajar statistika mahasiswa.

Sesuai dengan kesimpulan di atas, direkomendasikan kepada para Dosen pengampu statistika untuk menggunakan multimedia berbasis flash dalam proses pembelajarannya. Para pengajar yang mengampu materi yang dirasakan sangat sulit oleh para peserta didik, juga disarankan untuk mencoba membuat dan menggunakan multimedia berbasis flash.

\section{Ucapan Terima Kasih}

Penulis menyampaikan ucapan terima kasih kepada pihak-pihak yang telah mendukung terlaksananya penelitian ini, yakni: Direktur Penguatan 
Riset dan Pengembangan Kemenristekdikti, Ketua STKIP PGRI Pacitan, Kepala LPPM STKIP PGRI Pacitan, dan Segenap Mahasiswa STKIP PGRI Pacitan.

\section{Daftar Pustaka}

Arfiyani, A. Y., Haryono, H., \& Mulyani, B. (2014). Penerapan model pembelajaran problem solving dilengkapi macromedia flash untuk meningkatkan kreativitas dan prestasi belajar pada materi hidrokarbon siswa kelas X-5 SMA Negeri 3 Boyolali tahun pelajaran 2012/2013. Jurnal Pendidikan Kimia, 3(1), 111-116.

Asiyah, S., Mulyani, S., \& Nurhayati, N. D. (2013). Penerapan model pembelajaran learning cycle $5 \mathrm{E}$ berbantuan macromedia flash dilengkapi LKS untuk meningkatkan aktivitas dan prestasi belajar siswa pokok bahasan zat adiktif dan psikotropika kelas VIII SMPN 4 Surakarta Tahun pelajaran 2011/2012. Jurnal Pendidikan Kimia, 2(2), 56-65.

Bates, J., \& Bacon, J. (1995). Supporting interactive presentation for distributed multimedia applications. Multimedia Tools and Applications, 1(1), 47-78.

Bernstein, I. H. (2012). Applied multivariate analysis. New York: SpringerVerlag.

C Orlich, D. (2010). Teaching strategies: A guide to effective instruction. Wadrdwort: Cengange Learning.

Dai, D. Y., \& Sternberg, R. J. (2004). Motivation, emotion, and cognition: Integrative perspectives on intellectual functioning and development. Routledge.

Dale, E. (1946). The cone of experience. Audio-Visual Methods in Teaching, 1, 37-51.

Djamarah, S. B., \& Zain, A. (2006). Strategi belajar mengajar. Jakarta: Rineka Cipta.

Elliott, S., \& Littlefield, J. (2000). Educational psychology: Effective teaching, effective learning. Boston: McGraw-Hill.

Irawan, E. (2012). Analisis kesalahan dalam melakukan uji hipotesis rerata mahasiswa pendidikan bahasa dan sastra indonesia STKIP PGRI Pacitan. Makalah dipresentasikan di SENDIKMAD, Yogyakarta: Universitas Ahmad Dahlan.

Irawan, E. (2014). Pengantar statistika penelitian pendidikan. Yogyakarta: Aura Pustaka.

Johnson, R. A., \& Wichern, D. W. (2007). Applied multivariate statistical analysis. Boston: Prentice Hall.

Mawarni, E., Mulyani, B., \& Yamtinah, S. (2014). Penerapan peer tutoring dilengkapi animasi macromedia flash dan handout untuk meningkatkan 
motivasi berprestasi dan prestasi belajar siswa kelas XI IPA 4 SMAN 6 Surakarta tahun pelajaran 2013/2014 pada materi kelarutan dan hasil kali kelarutan. Jurnal Pendidikan Kimia, 4(1), 29-37.

Nitko, A. J., \& Brookhart, S. M. (2011). Educational assesment of students (6th ed.). Boston: Pearson Education, Inc.

Philips, R. (1997). The developer's handbook to interactive multimedia. Practical Guide for Educational Aplication, 38.

Ramsey, J. B. (1999). Why do students find statistics so difficult (pp. 10-18). Presented at the 52th Session of the ISI, Helsinki.

Reid, G. (2007). Motivating learners in the classroom: ideas and strategies. London: SAGE.

Rencher, A. C. (1998). Multivariate statistical inference and applications (Vol. 338). New York: John Wiley \& Sons.

Retnani, F. Y., Sukardjo, J. S., \& Utomo, S. B. (2014). Penerapan metode numbered heads together (nht) disertai macromedia flash untuk meningkatkan motivasi dan prestasi belajar siswa materi struktur atom, sistem periodik, dan ikatan kimia kelas XI IPA 4 SMA Negeri 2 Boyolali tahun pelajaran 2013/2014. Jurnal Pendidikan Kimia, 3(3), 57-65.

Sanders, D. H. (2001). Statistics: A first Course. Boston: McGraw-Hill Ryerson.

Sardiman, A. M. (2012). Interaksi dan motivasi belajar mengajar. Jakarta: Raja Grafindo Persada.

Sidhu, M. S. (2010). Instructional design for multimedia and theory of learning styles. In Technology-Assisted Problem Solving for Engineering Education: Interactive Multimedia Applications (pp. 12-29). IGI Global.

Slameto. (1995). Belajar dan faktor-faktor yang mempengaruhinya. Jakarta: Rineka Cipta.

Sutarti, T., Sugiyono, \& Irawan, E. (2015). The development of statistics learning media by using flash micromedia. Makalah dipresentasikan di the International Conference Concervation for Better Life, Semarang: Semarang State University.

Sutarti, T., Sugiyono, Irawan, E., \& Prasetyo, E. B. (2015). Jago membuat multimedia interaktif berbasis flash. Yogyakarta: Trussmedia.

Ulpah, M. (2009). Belajar statistika: mengapa dan bagaimana? Insania, 14(3), 325-435. 